\title{
Heterosis of Highland Maize (Zea mays L) Hybrids for Grain Yield and Yield Related Components
}

Shimelis Tesfaye ${ }^{1 *}$ and Berhanu Sime ${ }^{2}$

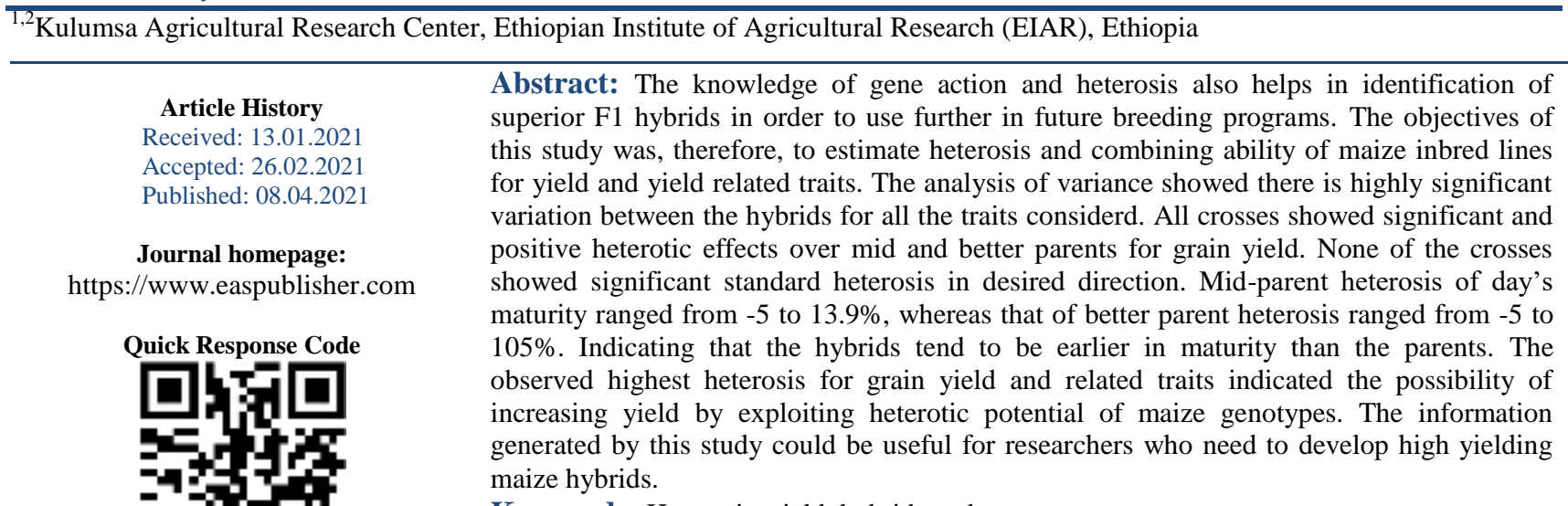

Keywords: Heterosis, yield, hybrids and gene.

Copyright ( $\odot 2021$ The Author(s): This is an open-access article distributed under the terms of the Creative Commons Attribution 4.0 International License (CC BY-NC 4.0) which permits unrestricted use, distribution, and reproduction in any medium for non-commercial use provided the original author and source are credited.

\section{INTRODUCTION}

Maize is the third most important cereal crops widely grown throughout the world after wheat and rice. The world maize production area in 2017 was around 190.63 million hectares, and that of wheat and rice was 220 million and 162.31 million hectares, respectively [1]. Maize surpasses wheat and rice in terms of actual production. Worldwide maize production was around 1033.74 billion tons in 2017 considerably more than wheat ( 757.92 million tons) or rice ( 488.6 million tons). In that year, the United States was the largest producer of maize with a production volume amounting to about 370.96 million metric tons. China and Brazil rounded off the top maize producing countries [1]. The share of Africa's maize production in 2017 was 58.21 million tons harvested from 23.71 million hectares.

Similarly, the demand for maize has been steadily growing in Ethiopia. It contributes to the greatest share of production and consumption along with other major cereal crops such as tef (Eragrostis tef (Zucc.) Trotter), wheat (Triticum aestivum L.) and sorghum (Sorghum bicolor L.) In 2016/17 main cropping season, cereals were cultivated on 10.3 million hectares, producing 25.38 million metric tons of grain [2]. This represents $81.27 \%$ of the total production area and $87.42 \%$ of grain production in the country. Among the cereal crops, maize ranks second to tef in area coverage and first in total production. The production of maize has been increasing over the years in the major maize producing regions of the Ethiopia. Recent reports of the Central Statistical Agency of Ethiopia showed that maize was produced on about 3.02 million hectares with total production of about 7.85 million tons in 2016/17 main cropping season. During the same year, an average national yield of $3.67 \mathrm{t} \mathrm{ha}^{-1}$ was recorded [2].

During the early stages of maize breeding in Ethiopia, the focus was the development of open pollinated varieties (OPVs) [3]. This was mainly due to the assumption that small-scale farmers did not have the skill required to manage hybrid maize [4], unavailability of improved germplasm locally for hybrid development, lack of experience in hybrid development and absence of seed producers. Later, the high yield realized on the state farms with hybrids imported from Kenya, Zimbabwe and Malawi in the early 1980s together with high yield potential recorded from some experimental hybrids in the research centers convinced the breeders to go for wide development and testing of maize hybrids locally. This led to a shift in the breeding strategy from development of only OPVs 
to development of both hybrids and OPVs in the early 1980s [5].

Currently, concentrated efforts are underway in the country by different maize research institutions to move more toward the use of hybrids varieties. To fulfill this aim, combining ability studies have prime importance in maize hybrid development since it provides information for the selection of parents and provides information on the nature and magnitude gene actions. With this aim in mind, this research was conducted with the objective to study heterosis and combining ability in maize (Zea mays L.) for yield and yield related traits.

\section{Materials ANd Methods Planting Materials}

The experiment was consisted of 48 testcrosses produced by crossing 24 inbred lines to two testers in line $\mathrm{x}$ tester mating design plus the parental lines and two standard checks (AMH851 and AMH853). The description of the lines is depicted in table 1. The Ambo Highland Maize Research Project introduced the inbred lines from CIMMYT-Zimbabwe in 2014.

\section{Methods}

The 48 F1 hybrids and the parental lines were tested in 2017 cropping seasons Kulumsa Agricultural research center in alpha-lattice design [18] and Randomized complete block design with two replication respectively in adjacent field. Each plot consisted of two rows with row length of $5.1 \mathrm{~m}$. Two Seeds were sown per hill and at 4-5 leaf stage thinned to one plant per hill. The distance between rows and between plants with in the row was maintained at $0.75 \mathrm{~m}$ and $0.25 \mathrm{~m}$, respectively. At sowing, P2O5 at the rate of $46 \mathrm{~kg} / \mathrm{ha}$ in a form of DAP and $35 \mathrm{~kg} / \mathrm{ha}$ of $\mathrm{N}$ in a form of urea was applied. At about booting stage, $35 \mathrm{~kg} / \mathrm{ha}$, $\mathrm{N}$ was also applied. All other field management practices including stalk borer and armyworm control were done as required. Data were collected on days to maturity, ear length, ear diameter, number of rows per ear, number of kernel rows per ear, 1000 kernel weight (g) and grain yield in $\mathrm{t} / \mathrm{ha}$. Before analysis of the data, both grain yield and 1000-kernel weight were adjusted to $12.5 \%$ moisture content.

\section{STATISTICAl AnAlysis}

Analysis of variance was conducted with the PROC MIXED procedure in [4] considering genotypes as fixed effects and replications and blocks within replications as random.

Heterosis expressed as increase or decrease of F1 hybrid value over mid-parent (relative heterosis), better parent (heterobeltiosis) and over the best commercial check (standard heterosis) were calculated for each character using the following formulas suggested by Hayes et al. [6].

$$
\begin{aligned}
& \left(\frac{\mathrm{F} 1-\mathrm{MP}}{\mathrm{MP}}\right) \times 100=\text { Heterosis over mid parent (relative heterosis) } \\
& \left(\frac{\mathrm{F} 1-\mathrm{BP}}{\mathrm{BP}}\right) \times 100=\text { Heterosis over better parent (heterobeltiosis) } \\
& \left(\frac{\mathrm{F} 1-\mathrm{STV}}{\mathrm{STV}}\right) \times 100 \text { Heterosis over check (standard heterosis) }
\end{aligned}
$$

Where: $\mathrm{F} 1=$ mean performance of $\mathrm{F} 1, \mathrm{MP}=$ mean mid-parental value $=(\mathrm{P} 1+\mathrm{P} 2) / 2, \mathrm{P} 1=$ mean performance of parent one, $\mathrm{P} 2=$ mean performance of parent two, $\mathrm{BP}=$ mean performance of better parent, $\mathrm{CC}=$ mean performance of the best commercial check.

Table-1: The Pedigree and source of the lines and testers used in the study

\begin{tabular}{|l|l|l|}
\hline Line code & Pedigree & Source \\
\hline L1 & (LPSC7-F96-1-2-1-1-B-B-B*/OFP9)-3-1-1-1-1-B-B-\# & CIMMYT/AHMBP \\
\hline L2 & (LPSC7-F96-1-2-1-1-B-B-B*/OFP39)-6-1-1-1-1-B-B-\# & CIMMYT/AHMBP \\
\hline L3 & (LPSC7-F71-1-2-1-2-B-B-B*/OFP1)-B-14-4-1-B-B-B-\# & CIMMYT/AHMBP \\
\hline L4 & (LPSC7-F71-1-2-1-2-B-B-B*/OFP2)-B-1-3-1-B-B-B-\# & CIMMYT/AHMBP \\
\hline L5 & (LPSC7-F71-1-2-1-2-B-B-B*/OFP3)-B-18-1-1-B-B-B-\# & CIMMYT/AHMBP \\
\hline L6 & CML539-B-\# & CIMMYT/AHMBP \\
\hline L7 & (CML539*/OFP9)-4-1-1-2-1-B-B-\# & CIMMYT/AHMBP \\
\hline L8 & (CML539*/OFP27)-2-1-2-1-1-B-B-\# & CIMMYT/AHMBP \\
\hline L9 & (CML539*/OFP14)-2-1-1-2-1-B-B-\# & CIMMYT/AHMBP \\
\hline L10 & (CML539*/OFP14)-2-1-3-1-2-B-B-\# & CIMMYT/AHMBP \\
\hline L11 & CML539*/OFP1)-B-6-1-1-B-B-B-\# & CIMMYT/AHMBP \\
\hline
\end{tabular}


Shimelis Tesfaye \& Berhanu Sime., EAS J Biotechnol Genet; Vol-3, Iss-2 (Mar-Apr, 2021): 47-52

\begin{tabular}{|c|l|c|}
\hline Line code & Pedigree & Source \\
\hline L12 & CML539*/OFP1)-B-11-2-1-B-B-B-\# & CIMMYT/AHMBP \\
\hline L13 & (CML539*/OFP4)-B-12-1-1-B-B-B-\# & CIMMYT/AHMBP \\
\hline L14 & CML442-\# & CIMMYT/AHMBP \\
\hline L15 & (CML442*/OFP1)-B-14-4-2-B-B-B-\# & CIMMYT/AHMBP \\
\hline L16 & (CML442*/OFP1)-B-18-2-2-B-B-B-\# & CIMMYT/AHMBP \\
\hline L17 & (CML442*/OFP4)-B-4-1-2-B-B-B-\# & CIMMYT/AHMBP \\
\hline L18 & (CML442*/OFP4)-B-17-3-2-B-B-B-\# & CIMMYT/AHMBP \\
\hline L19 & (CML395*/OFP105)-1-2-3-1-2-B-B-\# & CIMMYT/AHMBP \\
\hline L20 & (CML444*/OFP23)-6-3-1-1-2-B-B-\# & CIMMYT/AHMBP \\
\hline L21 & $([$ CML312/[TUXPSEQ]C1F2/P49-SR]F2-45-3-2-1-BB//INTA-F2-192- & CIMMYT/AHMBP \\
\hline L23 & (CML495*/OFP6)-B-3-3-3-B-B-\# & CIMMYT/AHMBP \\
\hline L24 & (CML495*/OFP6)-B-27-1-1-B-\# & CIMMYT/AHMBP \\
\hline & TESTER & \\
\hline T1 & FS59 & AMBO \\
\hline T2 & FS67 & AMBO \\
\hline & CHECKS & AMBO \\
\hline 1 & KOLBA (AMH853) & AMBO \\
\hline 2 & JIBAT (AMH 851) & \\
\hline
\end{tabular}

AHMBP = Ambo Highland Maize Breeding Program

\section{RESULTS AND DisCUSSIONS}

Effect of genotypes on the genetic variation of maize

The analysis of variance showed highly significant differences between the genotypes for grain yield, days to maturity and yield component traits indicating there is sufficient genetic variation among the tested genotypes. Several maize researchers also found statistically significant differences between the genotypes for grain yield and yield related traits in their study on heterosis and combining ability of maize [7$11]$.

Table-2: Line $\mathrm{x}$ tester analysis of variance for grain yield and yield related traits at Kulumsa in 2017

\begin{tabular}{|r|r|r|r|r|r|r|r|r|}
\hline Source & d.f. & MD & EL(cm) & ED $(\mathbf{c m})$ & KRPE & NKPR & TKW(g) & $\begin{array}{r}\text { GYF } \\
\text { t/ha }\end{array}$ \\
\hline Rep & 1 & $10.56^{\mathrm{ns}}$ & $0.10^{\mathrm{ns}}$ & $0.09^{\mathrm{ns}}$ & $1.17^{\mathrm{ns}}$ & $43.78^{*}$ & $111.3^{\mathrm{ns}}$ & $1.04^{\mathrm{ns}}$ \\
\hline Genotype & 71 & $36.36^{* *}$ & $25.37^{* *}$ & $0.31^{* *}$ & $1.97^{*}$ & $40.27^{* *}$ & $16147.6^{* *}$ & $28.49^{* *}$ \\
\hline Hybrid & 49 & $29.07^{*}$ & $3.76^{*}$ & $0.10^{* *}$ & $1.52^{*}$ & $18.39^{*}$ & $4350.73^{* *}$ & $2.24^{* *}$ \\
\hline Cross & 47 & $31.71^{*}$ & $3.73^{* *}$ & $0.11^{* *}$ & $1.70^{* *}$ & $21.21^{* *}$ & $4539.40^{* *}$ & $2.30^{*}$ \\
\hline Parent & 23 & $38.90^{*}$ & $6.06^{* *}$ & $0.38^{* *}$ & $1.60^{\mathrm{ns}}$ & $16.55^{* *}$ & $908.23^{* *}$ & $1.69^{* *}$ \\
\hline GCAL & 23 & $42.84^{* *}$ & $4.80^{* *}$ & $0.17^{* *}$ & $2.02^{* *}$ & $28.58^{* *}$ & $5130.90^{* *}$ & $2.22^{\mathrm{ns}}$ \\
\hline GCAT & 1 & $117.04^{*}$ & $7.61^{*}$ & $0.02^{\mathrm{ns}}$ & $13.72^{* *}$ & $1.26^{\mathrm{ns}}$ & $58641.3^{* *}$ & $22.18^{* *}$ \\
\hline SCALxT & 23 & $16.87 \mathrm{~ns}$ & $2.51^{*}$ & $0.06^{* *}$ & $0.85^{\mathrm{ns}}$ & $14.71^{\mathrm{ns}}$ & $1595.6^{* *}$ & $1.51 \mathrm{~ns}$ \\
\hline error & & 18.82 & 1.23 & 0.02 & 1.72 & 7.84 & 721.9 & 0.94 \\
\hline
\end{tabular}

$*, * *,=$ Significant at 0.05 and $0.01, \mathrm{GYF}=$ grain yield $\mathrm{t} \mathrm{ha}^{-1} ; \mathrm{MD}=$ days to maturity (days), EL=ear length $(\mathrm{cm}), \mathrm{ED}=$ ear diameter $(\mathrm{cm})$; NRPE=number of rows per ear (\#); NKPR= number of kernels per row (\#); TKW= thousand kernel weight $(\mathrm{g})$.

\section{Heterosis for yield and yield related traits}

Percent (\%) mid-parent (MPH), better parent $(\mathrm{BPH})$ and standard heterosis $(\mathrm{STH})$ were computed for grain yield and related traits (table 4). STH was considered only for grail yield. Both mid-parent and better parent heterosis for days to maturity are negative for eight and twenty-seven crosses respectively. For this trait, mid-parent heterosis ranged from -5 to $13.9 \%$ and better parent heterosis -5 to $105 \%$. This showed that hybrids tend to be earlier in maturity Compared to their parents. In this study, ear per plant, ear diameter, and number of rows per ear showed low/negligible level of heterosis (data not shown), whereas number of kernels per row and 1000 kernel weight produced relatively high and positive heterosis. Similar findings were reported by Zeleke [12], Kumar and Babu [13]. In their study on Combining ability and heterosis in maize for grain yield and yield components.

All crosses showed significant and positive heterotic effects over mid and better parent. The range of mid-parent and better parent for number of kernels per row was 21.4 to $68.4 \%, 13.6 \%$ to $57.4 \%$ respectively, whereas mid-parent, better parent for 1000 kernel weight was -101.1 to $47.4 \%,-35.4$ to $21.3 \%$ respectively (table 3 ). Kumar and Babu [13], in 
their study on Combining ability and heterosis in maize (Zea mays L.) for grain yield and yield components reported positive and significant heterosis for yield component traits. Rajesh et al. [14] and Talukder et al. [15] reported similar findings in their study on maize. Shushay [16] and Ziggiju [17], in their study on standard heterosis reported significant difference among genotypes for, number of kernels per row and thousandkernel weight.

\section{Heterosis for yield}

Percent (\%) mid-parent (MPH), better parent (BPH) and standard heterosis (STH) were computed for yield related traits (Table 3). All crosses showed significant and positive heterotic effects over mid and better parents for grain yield. None of the crosses showed significant standard heterosis in desired direction (Table 3). Mid parent heterosis for grain yield ranged from 156 to $384.2 \%$, for best parent heterosis from 102.9 to $278 \%$ and for standard heterosis over the best check Kolba ranged from -42.2 to $7.1 \%$ (Table 3 ). Zeleke [12] in his study on heterosis and combining ability for grain yield and yield component traits of maize in Eastern Ethiopia reported similar result. Kumar and Babu [13], in their study on Combining ability and heterosis in maize for grain yield and yield components reported significant values for mid parent, best parent and standard heterosis in desired direction for grain yield.

Table-3: heterosis for grain yield and agronomic traits of crosses among 24 lines and 2 testers evaluated at Kulumsa, 2017

\begin{tabular}{|c|c|c|c|c|c|c|c|c|c|}
\hline & Days to & aturity & Kernel & row & TKW & & Grain yi & & \\
\hline cross & MPH & HРH & MPH & HPH & MPH & HPH & МPH & HPH & STH \\
\hline L1XT1 & $2.1 * *$ & $1.8^{*}$ & $23.2 * *$ & $13.6^{*}$ & $15.4 * *$ & $-8.6 * *$ & $231.0 * *$ & $222.2 * *$ & -8.7 \\
\hline L1XT2 & -1 & $-1.9 *$ & $48.0^{* * *}$ & $38.6 * *$ & $21.8 * *$ & $-4.4 * *$ & $195.3 * *$ & $186.6^{* * *}$ & -18 \\
\hline L2XT1 & $2.3^{* *}$ & 1.3 & $43.3^{* *}$ & $35.9 * *$ & -0.4 & $-28.1 * *$ & $282.4 * *$ & $227.5 * *$ & -7.2 \\
\hline L2XT2 & 0.5 & $-2.0 *$ & $54.8 * *$ & $49.3 * *$ & $23.4 * *$ & $-11.5^{* *}$ & $219.9 * *$ & $173.3 * *$ & -22 \\
\hline L3XT1 & $-2.0 * *$ & $-3.8 * *$ & $47.3^{* *}$ & $37.3 * *$ & 0.4 & $-24.6^{* *}$ & $280.8 * *$ & $209.4 * *$ & -12 \\
\hline L3XT2 & $-3.7 * *$ & $-5.0 * *$ & $31.0 * *$ & $24.1 * *$ & $12.8 * *$ & $-15.9 * *$ & $196.3 * *$ & $140.1 * *$ & $-31.6^{*}$ \\
\hline L4XT1 & -1 & $-1.7 *$ & $49.9 * *$ & $40.9 * *$ & $-10.1 * *$ & $-35.4 * *$ & $281.9 * *$ & $159.9 * *$ & $-26.4^{*}$ \\
\hline L4XT2 & $-1.9 * *$ & $-4.4 * *$ & $58.9 * *$ & $51.9 * *$ & $11.7 * *$ & $-20.2 * *$ & $239.1 * *$ & $130.4 * *$ & $-34.3 * *$ \\
\hline L5XT1 & -0 & $-1.6^{*}$ & $45.5 * *$ & $37.4 * *$ & $5.5 * *$ & $-5.6 * *$ & $170.2 * *$ & $156.7 * *$ & -19 \\
\hline L5XT2 & -1 & $-1.7^{*}$ & $45.7 * *$ & $39.9 * *$ & $11.2 * *$ & $-1.5 * *$ & $180.0 * *$ & $166.8 * *$ & -16 \\
\hline L6XT1 & 0.9 & 0.3 & $35.0 * *$ & $33.7 * *$ & $17.8 * *$ & $-13.0 * *$ & $250.5 * *$ & $188.8 * *$ & -18 \\
\hline L6XT2 & -1 & $-3.0 * *$ & $34.2^{* * *}$ & $33.1 * *$ & $24.6 * *$ & $-8.6 * *$ & $227.2 * *$ & $168.9 * *$ & -23 \\
\hline L7XT1 & 0.8 & -0.4 & $48.7 * *$ & $43.9 * *$ & $12.4^{* *}$ & $-3.1 * *$ & $175.7 * *$ & $160.0 * *$ & $-26.4^{*}$ \\
\hline L7XT2 & 0 & -0.8 & $43.7 * *$ & $41.5 * *$ & $21.7 * *$ & $4.1 * *$ & $177.3 * *$ & $160.7 * *$ & $-25.7 *$ \\
\hline L8XT1 & 0.7 & 0.1 & $43.4 * *$ & $40.3 * *$ & $27.0 * *$ & $-2.8 * *$ & $223.2 * *$ & $170.7 * *$ & -23 \\
\hline L8XT2 & $-1.4 * *$ & $-1.9 *$ & $32.9 * *$ & $27.8 * *$ & $26.5 * *$ & $-4.0 * *$ & $244.0 * *$ & $187.4 * *$ & -18 \\
\hline L9XT1 & 0.9 & -0.1 & $51.0 * *$ & $32.0 * *$ & $9.6 * *$ & $-19.3 * *$ & $384.2 * *$ & $231.8 * *$ & -6 \\
\hline L9XT2 & $1.9 * *$ & 0.4 & $56.7 * *$ & $39.1 * *$ & $31.1 * *$ & $-4.1 * *$ & $371.3 * *$ & $222.3 * *$ & -8.1 \\
\hline L10XT1 & $1.9 * *$ & -0.2 & $50.0 * *$ & $31.2 * *$ & $8.9 * *$ & $-13.5^{* * *}$ & $250.0 * *$ & $178.9 * *$ & -21 \\
\hline L10XT2 & -0 & -1 & $33.9 * *$ & $18.8^{* *}$ & $36.5^{* *}$ & $7.6^{* *}$ & $287.2 * *$ & $207.8 * *$ & -12 \\
\hline L11XT1 & $2.8 * *$ & $2.0 *$ & $24.0 * *$ & $20.9 * *$ & $16.8 * *$ & $-8.1 * *$ & $274.5 * *$ & $169.0 * *$ & -24 \\
\hline L11XT2 & -1 & $-2.2 * *$ & $23.3 * *$ & $18.2 * *$ & $24.0 * *$ & $-3.1 * *$ & $325.7 * *$ & $205.2 * *$ & -13 \\
\hline L12XT1 & 0.6 & 0 & $26.5 * *$ & $22.8 * *$ & $29.4 * *$ & $4.4 * *$ & $207.4 * *$ & $150.2 * *$ & $-29.1^{*}$ \\
\hline L12XT2 & 1 & 0 & $23.4 * *$ & $17.8 * *$ & $29.5 * *$ & $3.6 * *$ & $208.3 * *$ & $150.4 * *$ & $-28.6^{*}$ \\
\hline L13XT1 & $96.1 * *$ & $2.2 *$ & $68.4 * *$ & $44.7 * *$ & $3.7 * *$ & $-14.3 * *$ & $276.9 * *$ & $220.8 * *$ & -9.1 \\
\hline L13XT2 & $94.1 * *$ & $-2.1 * *$ & $58.0 * *$ & $37.8 * *$ & $9.0 * *$ & $-10.7 * *$ & $180.5^{* *} *$ & $138.2 * *$ & $-32.1 *$ \\
\hline L14XT1 & $105.7 * *$ & $3.9 * *$ & $43.4 * *$ & $41.7 * *$ & $-9.5 * *$ & $-17.1 * *$ & $198.6^{* * *}$ & $186.6^{* *}$ & -19 \\
\hline L14XT2 & $97.1 * *$ & -0.8 & $22.8 * *$ & $19.4 * *$ & $24.3 * *$ & $12.7 * *$ & $204.5 * *$ & $191.3 * *$ & -17 \\
\hline L15XT1 & $99.4 * *$ & 0.5 & $51.4 * *$ & $40.7 * *$ & $5.3 * *$ & -16 & $198.8 * *$ & $148.6 * *$ & $-29.6^{*}$ \\
\hline L15XT2 & $94.3 * *$ & $-2.2 * *$ & $32.1 * *$ & $20.8 * *$ & $28.9 * *$ & $1.5^{* *}$ & 169.0 ** & $123.2 * *$ & $-36.4 * *$ \\
\hline L16XT1 & $101.4 * *$ & 1.4 & $41.5 * *$ & $34.9 * *$ & $-3.7 * *$ & $-12.1 * *$ & $257.5 * *$ & $162.7 * *$ & -26 \\
\hline L16XT2 & $92.7 * *$ & $-2.9 * *$ & $55.6^{* * *}$ & $50.9 * *$ & 11.0 *** & 0.4 & $176.7 * *$ & $102.9 * *$ & $-42.2 * *$ \\
\hline L17XT1 & $101.2^{* *}$ & 1.3 & $33.2 * *$ & $28.6^{* *}$ & $6.1 * *$ & $-17.2^{* *}$ & $234.0 * *$ & $178.4 * *$ & -21 \\
\hline L17XT2 & $95.5 * *$ & $-1.6^{*}$ & $39.9 * *$ & $32.9 * *$ & $26.2 * *$ & $-2.2 * *$ & $193.4 * *$ & $144.0 * *$ & $-30.5^{*}$ \\
\hline L18XT1 & $102.1 * *$ & $1.8^{*}$ & $47.5^{* * *}$ & $37.3 * *$ & $3.3 * *$ & $-27.8 * *$ & $289.9 * *$ & $206.7 * *$ & -13 \\
\hline L18XT2 & $95.1 * *$ & $-1.8 *$ & $24.7 * *$ & $14.3 * *$ & $47.4^{* *}$ & $2.4 * *$ & $297.3 * *$ & $211.9 * *$ & -11 \\
\hline
\end{tabular}




\begin{tabular}{|c|c|c|c|c|c|c|c|c|c|}
\hline \multirow[b]{2}{*}{ cross } & \multicolumn{2}{|c|}{ Days to maturity } & \multicolumn{2}{|c|}{ Kernels/row } & \multicolumn{2}{|l|}{ TKW } & \multicolumn{3}{|c|}{ Grain yield } \\
\hline & МРH & HPH & MPH & HPH & MPH & HPH & MPH & HPH & STH \\
\hline L19XT1 & $99.9 * *$ & 0.7 & $32.6 * *$ & $29.1 * *$ & $18.9 * *$ & $11.0 * *$ & $168.2 * *$ & $167.1 * *$ & -24 \\
\hline L19XT2 & $97.5 * *$ & -0.5 & $28.2 * *$ & $28.2 * *$ & $31.2 * *$ & $21.3 * *$ & $156.0 * *$ & $155.8 * *$ & $-26.9 *$ \\
\hline L20XT1 & $105.1 * *$ & $3.2 * *$ & $55.1 * *$ & $47.8 * *$ & $12.7 * *$ & $-13.0 * *$ & $347.3 * *$ & $278.0 * *$ & 7.1 \\
\hline L20XT2 & $97.3 * *$ & -0.7 & $48.3 * *$ & $43.7 * *$ & $42.3 * *$ & $9.0 * *$ & $269.2 * *$ & $211.2 * *$ & -11 \\
\hline L21XT1 & $100.9 * *$ & 1.2 & $52.3 * *$ & $43.6 * *$ & $14.3^{* *}$ & $-6.8 * *$ & $250.8 * *$ & $172.5^{* *}$ & -23 \\
\hline L21XT2 & $100.4 * *$ & 0.9 & $32.3 * *$ & $26.7 * *$ & $27.2 * *$ & $2.9 * *$ & $278.9 * *$ & $193.8 * *$ & -16 \\
\hline L22XT1 & $102.6 * *$ & $2.0^{*}$ & $21.4 * *$ & $17.7 * *$ & $8.4 * *$ & $-19.5 * *$ & $297.2 * *$ & $212.0 * *$ & -12 \\
\hline L22XT2 & $97.3 * *$ & -0.7 & $27.9 * *$ & $22.0 * *$ & $28.9 * *$ & $-4.8 * *$ & $261.4 * *$ & $183.3 * *$ & -19 \\
\hline L23XT1 & $103.1 * *$ & $2.2 * *$ & $36.2 * *$ & $33.9 * *$ & $10.1 * *$ & $-12.9 * *$ & $253.7 * *$ & $164.7 * *$ & -25 \\
\hline L23XT2 & $98.4 * *$ & -0.2 & $57.6 * *$ & $57.4^{* *}$ & $27.3 * *$ & -0.2 & $266.1 * *$ & $173.5^{* * *}$ & -22 \\
\hline L24XT1 & $102.4 * *$ & $1.9^{*}$ & $27.1 * *$ & $23.6^{* *}$ & $23.9 * *$ & $-5.1 * *$ & $267.6 * *$ & $203.3^{* *}$ & -14 \\
\hline L24XT2 & $92.2 * *$ & $-3.3 * *$ & $29.4 * *$ & $23.8 * *$ & $17.0 * *$ & $-11.0 * *$ & $249.6 * *$ & $187.7 * *$ & -18 \\
\hline $\mathrm{CD}_{(\mathrm{MP}) 0.05}$ & 5.5 & 6.29 & 5.1 & 5.9 & 45.7 & 53 & 1.95 & 2.25 & 2.25 \\
\hline $\mathrm{CD}_{(\mathrm{MP}) 0.01}$ & 7.2 & 8.34 & 6.8 & 7.82 & 60.5 & 70 & 2.58 & 2.98 & 2.98 \\
\hline
\end{tabular}

$\mathrm{CD}_{(\mathrm{BP})}=$ Critical difference for heterosis over better parent; $\mathrm{GY}=$ grain yield $\left(\mathrm{t} \mathrm{ha}^{-1}\right) ; \mathrm{MD}=$ days to maturity (days); $\mathrm{TKW}=$ thousand kernel weight

\section{Conclusion}

Maize is the third most important cereal crops widely grown throughout the world after wheat and rice. The demand for maize has been steadily growing in Ethiopia. It contributes to the greatest share of production and consumption along with other major cereal crops. The objectives of this study was, therefore, to estimate heterosis and combining ability of maize inbred lines for yield and yield related traits. The experiment was consisted of 48 testcrosses produced by crossing 24 inbred lines to two testers in line $\mathrm{x}$ tester mating design plus the parental lines and two standard checks (AMH851 and AMH853). The analysis of variance showed highly significant differences between the genotypes for grain yield, days to maturity and yield component traits indicating there is sufficient genetic variation among the tested genotypes. Mid-parent heterosis of days to maturity ranged from -5 to $13.9 \%$ and better parent heterosis -5 to $105 \%$. This showed that hybrids tend to be earlier in maturity Compared to their parents. All crosses showed significant and positive heterotic effects over mid and better parents for grain yield. None of the crosses showed significant standard heterosis in desired direction.

\section{REFERENCES}

1. FAOSTAT. (2018). The Food and Agricultural Organization of the United Nations: The statistical database [Online]. Available at http://faostat.fao.org

2. CSA. (2017). Agricultural Sample Survey 2016/2017: Report on area and production of major crops (private peasant holdings, 'Meher' season). Statistical Bulletin. Vol. 1. CSA, Addis Ababa, Ethiopia.

3. Benti, T. (1992). The need and objectives of the first national maize workshop. 3. In Benti Tolessa and Joel, K. R. (eds.), the first national workshop, May 5-7 ${ }^{\text {th }} 1992$. Addis Ababa, Ethiopia.

4. Nigussie, M., Tanner, D., \& Twumasi-Afriyie, S. (Eds.). (2002). Enhancing the Contribution of Maize to Food Security in Ethiopia: Proceedings of the Second National Maize Workshop of Ethiopia: 12-16 November 2001, Addis Ababa, Ethiopia. CIMMYT.

5. Legesse, W., Mosisa, W., Berhanu, T., Girum, A., Wende, A., Solomon, A., \& Belayneh, A. (2011). Genetic improvement of maize for mid-altitude and lowland sub-humid agro-ecologies of Ethiopia. In Meeting the Challenges of Global Climate Change and Food Security through Innovative Maize Research (p. 24).

6. Hayes, H. K., Immer, F. R., \& Smith, D. C. (1955). Methods of plant breeding. Methods of plant breeding. (2nd ed).

7. Seyoum, A., Wegary, D., \& Alamerew, S. (2016). Test cross performance and combining ability of elite highland maize (Zea Mays L.) Inbred Lines at Jimma, South West Ethiopia. International Journal of Trend in Research and Development, 3(2), 1326.

8. Abakemal, D., Shimelis, H., \& Derera, J. (2016). Analyses of Combining Ability and Genotype-ByEnvironment Interaction of Quality Protein Maize Inbred Lines Adapted to Tropical-Highlands. Crop science, 56(6), 3078-3089.

9. Bullo, T., \& Dagne, W. (2016). Combining ability of inbred lines in quality protein maize (QPM) for varietal improvement. International journal of plant breeding and crop Science, 3(1), 079-089.

10. Keno, T., Regasa, M. W., \& Zeleke, H. (2017). Combining ability and heterotic orientation of midaltitude sub-humid tropical maize inbred lines for grain yield and related traits.

11. Noëlle, M. A. H., Richard, K., Vernon, G., Martin, Y. A., Laouali, M. N., Liliane, T. N., \& Godswill, 
N. N. (2017). Combining ability and gene action of tropical maize (Zea mays L.) inbred lines under low and high nitrogen conditions. Journal of Agricultural Science, 9(4), 222-235.

12. Zeleke, H. (2015). Heterosis and combining ability for grain yield and yield component traits of maize in eastern Ethiopia. Science, Technology and Arts Research Journal, 4(3), 32-37.

13. Kumar, S. P., \& Babu, D. R. (2016). Combining ability and heterosis in maize (Zea mays L.) for grain yield and yield components. International Journal of Agriculture, Environment and Biotechnology, 9(5), 763.

14. Rajesh, M., Sivanandhan, G., Subramanyam, K., Kapildev, G., Jaganath, B., Kasthurirengan, S., \& Ganapathi, A. (2014). Establishment of somatic embryogenesis and podophyllotoxin production in liquid shake cultures of Podophyllum hexandrum Royle. Industrial Crops and Products, 60, 66-74.
15. Talukder, M. Z. A., Karim, A. S., Ahmed, S., \& Amiruzzaman, M. (2016). Combining ability and heterosis on yield and its component traits in maize (Zea mays L.). Bangladesh Journal of Agricultural Research, 41(3), 565-577.

16. Shushay, W. A. (2014). Standard heterosis of maize (Zea mays L.) inbred lines for grain yield and yield related traits in central Rift Valley of Ethiopia. Journal of Biology, Agriculture and Healthcare, 4(23), 31-37.

17. Mesenbet, Z., Zeleke, H., \& Wolde, L. (2016). Standard heterosis of pipeline maize (Zea mays L.) hybrids for grain yield and yield related traits at Pawe, Northwestern Ethiopia. J Plant Breed Crop Sci, 3(2), 135-144.

18. Patterson, H.D., \& Williams, E.R. (1976). A new class resolvable incomplete block designs.

Cite This Article: Shimelis Tesfaye \& Berhanu Sime (2021). Heterosis of Highland Maize (Zea mays L) Hybrids for Grain Yield and Yield Related Components. EAS J Biotechnol Genet, 3(2), 47-52. 